\title{
A DEMOCRACIA NAS AUDIÊNCIAS PÚBLICAS EM CONTROLE DE CONSTITUCIONALIDADE CONCENTRADO NO BRASIL
}

\author{
DEMOCRACY IN THE PUBLIC AUDIENCES IN CONCENTRATED CONTROL OF \\ CONSTITUTIONALITY IN BRAZIL
}

\section{Andrey Lucas Macedo Correa}

Mestre em História Política pela Universidade Federal de Uberlândia (UFU)

Graduado em Direito pela Universidade Federal de Uberlândia (UFU)

Pesquisador-fundador e Secretário-Geral do Laboratório Americano de Estudos Constitucionais Comparados - LAECC/PPGD-UFU/CLACSO.

E-mail: andreylucas93@hotmail.com

\author{
Alexandre Walmott Borges \\ Doutor em Direito pela Universidade Federal de Santa Catarina (UFSC). \\ Doutor em História pela Universidade Federal de Uberlândia (UFU) \\ Mestre e graduado em Direito pela Universidade Federal de Santa Catarina (UFSC) \\ Atualmente é professor dos Programas de pós-graduação em \\ Direito da Universidade Federal de Uberlândia (UFU) e da \\ Universidade Estadual Paulista Júlio de Mesquita Filho (UNESP). \\ E-mail:walmott@gmail.com
}

\section{Karina Guimarães Pinhão}

Mestre em Ciências Jurídico-Políticas com Menção em Direito Constitucional pela Universidade de Coimbra com período sanduíche junto à École de Hautes Études en Sciences Sociales (EHESS) em Paris. Especialista em Direito Civil-Constitucional pela Universidade do Estado do Rio de Janeiro (UERJ). Graduada em Direito pela Pontifícia Universidade Católica do Rio de Janeiro (PUCRio). Pesquisadora do Laboratório Americano de Estudos Constitucionais Comparados - LAECC/PPGD-UFU. Advogada.

E-mail: pinhao.karina@gmail.com

Recebido em: 06/10/2018

Aprovado em: 16/02/2019

RESUMO: O presente trabalho tem por objetivo analisar como as audiências públicas podem contribuir para a legitimação democrática no controle de constitucionalidade face ao dilema contramajoritário da jurisdição constitucional. E, como estas audiências refletem nos limites da capacidade institucional do Judiciário no que diz respeito a construção de uma sociedade democrática. Para tanto, se fará uma breve exposição crítica de como audiências encontram-se previstas no ordenamento jurídico brasileiro e uma análise de como são aplicadas através das audiências já realizadas pelo Supremo Tribunal Federal. Por fim, se contrapõem as teses acerca da democracia contida nas doutrinas de Habermas e Iris Marion Young a fim de trazer a lume os limites da capacidade institucional das audiências públicas. Por fim, cumpre registrar que o estudo foi realizado de forma empírica e não tem a pretensão de resolver a importante problemática do tema, mas trazer uma nova perspectiva sobre o assunto.

Palavras chave: Legitimidade Democrática; Audiências Públicas; Jurisdição Constitucional. 


\begin{abstract}
This study aims to examine how public audiences can contribute to democratic legitimacy in constitutional control over the counter-majoritarian dilemma of constitutional jurisdiction. And as these audiences reflect the limits of the institutional capacity of the judiciary as regards the construction of a democratic society. Therefore, it will make a brief critical exposition of how audiences are envisaged in the Brazilian legal system and an analysis of how they are applied through the hearings already held by the Brazilian Supreme Court. Finally, seeks the analyses of the thesis about democracy contained in the doctrines of Habermas and Iris Marion Young in order to bring to light the limits of institutional capacity of public hearings. Finally, it noted that the study was conducted empirically and does not purport to address the important issue of the problem, but bring a new perspective on the subject.
\end{abstract}

Key words: democratic legitimacy; public hearings; constitutional jurisdiction.

SUMÁRIO: Introdução: o dilema contra-majoritário da jurisdição constitucional; 1 As audiências públicas; 1.1 A inserção das Audiências Públicas nos Processos de Controle de Constitucionalidade concentrado; 1.2 Breves comentários acerca da legislação pertinente; 1.3 Uma breve análise das audiências públicas já realizadas pelo Supremo Tribunal Federal no controle de constitucionalidade concentrado; 2 Uma contribuição para a democratização da Jurisdição Constitucional ou uma tentativa para tanto?; 2.1 Democratização da Jurisdição Constitucional; 2.2 Limites da Capacidade Institucional; Conclusão; Referências.

\title{
INTRODUÇÃO: O DILEMA CONTRA-MAJORITÁRIO DA JURISDIÇÃO CONSTITUCIONAL
}

"E afirmo: a maioria é ninguém e a minoria é todo mundo"

(Deleuze)

Dentro da jurisdição constitucional, o ativismo judicial é uma problemática que atenta a todos e que transcende a questão da interpretação criativa do juiz no controle de constitucionalidade. Esta realidade acaba perpassando pelo problema dos limites entre Direito e Política, refletindo na própria crise da democracia representativa no atendimento aos clamores populares ${ }^{1}$.

As primeiras marcas do ativismo judicial foram verificadas na atuação da Suprema Corte norte-americana no caso Dred Scott v. Sandford em 1857, através do qual este se revelou de forma conservadora ao amparar a segregação racial. Após certo período, é possível observar a manutenção dessa tendência conservadora por parte desta Corte nesse período, por exemplo, no conhecido caso Lochner v. New York (1905) no qual entendeu-se que a lei que garantia o máximo de horas de trabalho diárias em padaria fosse considerada inconstitucional por violação à liberdade contratual. De acordo com a Suprema Corte dos EUA, a liberdade contratual estaria inclusa na $14^{\mathrm{a}}$ emenda da Constituição daquele país por interpretação da cláusula do "due process". Assim sendo, dá-se início ao que é conhecido por Era Lochner que durou de 1905-1937, cuja principal característica foi o ativismo judicial conservador por parte deste tribunal.

O fim deste período se deu pela mudança de orientação no caso West Coast v. Parrish (1937) quando se passou a tomar uma atitude de autocontenção, ou seja, contrária ao intervencionismo estatal. Neste caso foi questionada a constitucionalidade de uma lei do Estado de Washington a

${ }^{1}$ TEXEIRA, Anderson Vichinkeski. Ativismo judicial: nos limites entre racionalidade jurídica e decisão política. In: Revista Direito GV, nº. 8(1). São Paulo. Jan-Jul. 2012, pp. 37-57.

Revista de Direito Brasileira | Florianópolis, SC | v. 22 | n. 9 | p. 29-49 |Jan./Abr. 2019 
qual estabelecia o salário mínimo. Este salário mínimo, por consequência, geraria uma restrição à liberdade contratual. Por outro lado, significava a proteção à comunidade a qual a Suprema Corte Norte-americana entendeu que cumpriria proteger. Assim sendo, diferentemente da atitude que continha durante a Era Lochner, a partir da década de 50, essa Corte passa a ter uma postura ativista em favor de direitos fundamentais face a imprescindibilidade da tutela de tais direitos e dos valores envolvidos.

No Brasil, o debate acerca do ativismo judicial se destaca principalmente sobre a ineficiência e a omissão do poder legislativo na efetivação de direitos fundamentais. Por este motivo, está altamente intrincado com o processo de judicialização da política e das relações sociais, o qual observa a expansão da atuação do Poder Judiciário como consequência do aumento da normatização da sociedade ${ }^{2}$. No entanto, apesar de $\operatorname{primos}^{3}$, ativismo judicial e judicialização não se confundem. $\mathrm{O}$ ativismo judicial pode ser identificado para além da judicialização, cuidando-se muito mais da efetivação de direitos através das decisões judiciais ${ }^{4}$. Assim sendo, envolvem a questão da motivação e fundamentação das decisões judiciais.

Além do fenômeno do ativismo judicial, no contexto do constitucionalismo brasileiro há o incremento de judicialização de políticas pelo caráter analítico e de organicidade prolixa das constituições nacionais. Sobretudo a partir do texto de 1988, vários conteúdos inseridos no texto constitucional ganharam o feitio de normas de possível exigência ou tutela judicial. Por esta razão, houve o incremento de demandas judicializadas em busca de tutela judicial para matérias variadas como acesso aos serviços de saúde, proteção do ambiente, funcionamento do sistema carcerário e, em extremo, a colmatação de omissões legislativas, de ausência de normas infraconstitucionais eficacizantes de direitos constitucionalmente estatuídos.

De outro lado, a configuração do sistema constitucional de controle de constitucionalidade resultou na 'exuberância' de formas de controle e, como consequência, a judicialização de contingentes de matérias constitucionais. Assim, o sistema brasileiro apresenta a prodigalidade de instrumentos de controle de constitucionalidade talvez sem igual no mundo. Há o funcionamento sincrônico de controle difuso e concentrado, espraiando por todo o sistema judicial o controle de constitucionalidade, ao mesmo tempo que o macrocontrole pode ser exercido pelo STF.

$\mathrm{O}$ funcionamento sincrônico de controle difuso e concentrado ainda vem acompanhado da duplicidade de controle decorrente da forma federativa. Com 26 constituições estaduais, uma lei orgânica distrital (em parte equiparada à norma constitucional estadual), o sistema permite o controle tanto tendo por parâmetro a constituição federal como as constituições estaduais. $\mathrm{O}$ resultado é também o deslocamento de quantidades de matérias à judicialização, via controle de constitucionalidade.

No que toca ao controle de constitucionalidade, além das formas de controle por difusão ou concentração, e da forma dupla de controle federativo, o sistema brasileiro determinou que alguns princípios federativos sobre finanças públicas, políticas de saúde e direitos fundamentais sejam controlados por uma via específica de intervenção da União nos Estados membros por decisão judicial que é a representação interventiva (artigo 34 c/c 36, ambos da Constituição). Vez mais, os conteúdos políticos são deslocados por força da organização da constituição ao crivo do judiciário.

O sistema de controle de constitucionalidade brasileiro pós 1988 concentrou no judiciário a dupla via de solução de possíveis omissões legislativas. De maneira pouco usual nos sistemas de

\footnotetext{
${ }^{2}$ BARROSO, Luís Roberto. Judicialização, ativismo judicial e legitimidade democrática. In: Revista (Syn)theses, volume 5, n.1, 2012. pp. 2-5

${ }^{3}$ Ibid. p. 6.

4 "Em todos os casos referidos acima, o Judiciário decidiu porque era o que lhe cabia fazer, sem alternativa. Se uma norma constitucional permite que dela se deduza uma pretensão, subjetiva ou objetiva, ao juiz cabe dela conhecer, decidindo a matéria. Já o ativismo judicial é uma atitude, a escolha de um modo específico e proativo de interpretar a Constituição, expandindo o seu sentido e alcance. Normalmente ele se instala em situações de retração do Poder Legislativo, de um certo descolamento entre a classe política e a sociedade civil, impedindo que as demandas sociais sejam atendidas de maneira efetiva.". Ibid. p. 6
}

Revista de Direito Brasileira | Florianópolis, SC | v. 22 | n. 9 | p.29-49 |Jan./Abr. 2019 
controle de constitucionalidade, permite o sistema brasileiro que o judiciário colmate possíveis omissões legislativas de produção de normas concretizadoras da constituição, tanto no controle difuso, pelo mandado de injunção, como no controle concentrado, pela ação direta de inconstitucionalidade por omissão.

Com a menção à ação direta de inconstitucionalidade por omissão, vale também dizer que o sistema concentrado ou abstrato de controle de constitucionalidade ainda se há por apresentar pluralidade de ações de controle: a já vista ação direta de inconstitucionalidade por omissão; a ação direta de inconstitucionalidade - comissiva -; a ação declaratória de constitucionalidade, na peculiar forma de confirmação da presunção de validade constitucional da norma por uma espécie de 'sanção' judicial; e a arguição de descumprimento de preceito fundamental, funcionando como remédio residual e supletivo, no caso de não se encontrar tutela no controle difuso, ou nas várias outras ações de controle abstrato ou concentrado.

A combinação de texto constitucional esquematicamente prolixo e acentuadamente analítico, com ampliação de inúmeras vias ou possibilidades de controle judicial de constitucionalidade leva ao deslocamento de supercontinente de matérias ao judiciário. As correlações podem ser tanto cum hoc ergo propter hoc, ou seja, constituição prolixa e analítica acontece com o simultâneo de sistema hipertrofiado de controle de constitucionalidade (e de judicialização), como post hoc ergo propter $h o c$, ou seja, constituição prolixa e analítica gera sistema judicializado e com formas dilatadas de controle de constitucionalidade.

Dadas as diferenças contextuais histórico-políticas entre a Suprema Corte norte-americana e o Supremo Tribunal Federal no Brasil, é possível enxergar a formação de uma jurisprudência pendular no ativismo judicial que vai de decisões mais progressistas no sentido de proteção aos direitos fundamentais, à decisões mais conservadoras, deixando à cargo dos demais poderes a atribuição de efetivação dos direitos fundamentais previstos na Constituição. Tal figura pendular da atuação da jurisdição constitucional oscila de acordo com o grau de prestígios dos demais poderes (Executivo e Legislativo) ${ }^{5}$ e com a ideologia do julgador ${ }^{6}$. Assim sendo, quanto maior o prestígio do Poder Legislativo e Executivo maior é a demanda pela autocontenção do Poder Judiciário e, por conseguinte, quanto menor o prestígio daqueles dois poderes, maior a demanda de postura positiva por parte do poder judiciário para salvaguarda de direitos negligenciados pelos demais poderes ${ }^{7}$.

\footnotetext{
${ }^{5}$ BOLONHA, Carlos Alberto Pereira das Neves; GANEM, Fabrício Faroni; RANGEL, Henrique. A Supremacia Judicial em sua Essência: para além do casuísmo teórico. In: Sequência, n. 66, Florianópolis. jul. 2013. pp. 261-282. Doi: http://dx.doi.org/10.5007/2177-7055.2013v34n66p261.

6 "O fator ideológico estará presente no método, que dele não ficará livre, como também estará presente na atividade cognitiva desenvolvida pelo observador que aplica o método, e não deve ser visto apenas como elemento perturbador do conhecimento científico, mas também como elemento que o ilumina e faz avançar.(...) Quando, na apresentação de um método e também na sua utilização não são explicitadas as condições ideológicas, sociológicas, econômicas e culturais do método utilizado, condições estas que devem explicitar as possíveis tarefas políticas às quais se pode prestar o método, mais distante fica uma pretensa verdade, ou pelo menos de uma demonstração possível da realidade.".( CADEMARTORI, Luiz Henrique Urquhart; ESTEVES, João Luiz Martins. A ideologia da neutralidade: uma abordagem sobre o juspositivismo normativista e seus limites frente à democracia social. Scientia Iuris, Londrina, v.17, n.2, dez.2013. DOI: 10.5433/2178-8189.2013v17n2p193. p.199.

Igualmente, Pierce Jr. Analisa quantativamente a questão: Every study of circuit court decisions that has looked at the question has found that ideological preferences help to explain patterns of decisions in cases in which courts review agency actions. Most studies found large ideologically-based differences in outcomes. Remarkably, three of the studies had identical findings with respect to the explanatory power of the ideological preferences of judges. Each of the three found that a circuit court panel was $31 \%$ more likely to uphold an agency action when the action was consistent with the ideological preferences of the members of the panel than when the action was inconsistent with those preferences. Thus, ideology is by far the most important of the explanatory variables that have been studied" PIERCE JR, R. J. What Do the Studies of Judicial Review of Agency. Admin. L. Rev. (Forthcoming)., Washington, 2010. p.10

${ }^{7}$ Não assim, porém, no que toca ao Congresso Nacional. Nos últimos anos, uma persistente crise de representatividade, legitimidade e funcionalidade no âmbito do Legislativo tem alimentado a expansão do Judiciário nessa direção, em nome da Constituição, com a prolação de decisões que suprem omissões e, por vezes, inovam na ordem jurídica, com Revista de Direito Brasileira | Florianópolis, SC | v. 22 | n. 9 | p. 29-49 |Jan./Abr. 2019
} 
Em suma, focando-se no contexto brasileiro, a crescente crise na representatividade, legitimidade e funcionalidade democrática contribuiu para a judicialização e, sobretudo, para o ativismo judicial, na medida em que transforma o Poder Judiciário na última esperança na luta pelos direitos contidos na Constituição cuja regulamentação, muitas vezes necessária, é negligenciada de forma reiterada pelos demais poderes (executivo e legislativo).

Por conseguinte, um aspecto fulcral do ativismo judicial é a maleabilidade do raciocínio jurídico o que perpassa pela apropriação do discurso político em sede judicial ${ }^{8}$. Portanto, o ativismo judicial acaba por refletir-se nos limites entre Direito e Política que possuem dimensões para além da discussão acerca da separação dos poderes.

Contudo, apenas para uma contextualização sucinta do tema, no que atine a judicialização da política, argumenta-se que há ofensa à separação dos poderes ${ }^{9}$ na medida em que o Judiciário estaria à decidir questões políticas e sociais nos lugares dos órgãos (Executivo e o Legislativo) que tradicionalmente são designados à tratar destes assuntos sobrepondo-se, assim, à estes poderes ${ }^{10}$. Nesta perspectiva, isto configuraria uma transferência de poder para os juízes os quais não são eleitos pelo povo e consequentemente não teriam a responsabilidade política de representar seus interesses, violando-se com isso o princípio da separação dos poderes. No entanto, a legitimidade do Judiciário para atuar na esfera política decorre da própria previsão constitucional, o que se justifica tendo em vista que há mesmo outros órgãos públicos que mesmo não se submetendo ao sufrágio universal exercem poderes políticos ${ }^{11}$. Logo, o Poder Judiciário estaria legitimado pela própria Constituição, além de não poder se afastar às demandas que lhe são propostas $^{12}$ face ao princípio da indisponibilidade da jurisdição.

caráter normativo geral. BARROSO, Luís Roberto. Op. Cit. p. 9

${ }^{8}$ TEXEIRA, Anderson Vichinkeski. Op. Cit. p. 39.

${ }^{9}$ Atenta-se que não há mais espaço, todavia, para a visão tradicional da separação dos poderes, cuja compreensão já sofreu modificações. Neste sentido, destaca-se: "Tais circunstâncias se põem com a transformação política operada pelo Estado Democrático de Direito, quando a própria noção de democracia é transladada para um locus legitimador não mais meramente formal, senão, principalmente, substancial, apesar de tal já estar presente no âmbito do Estado Social, implicando que a noção de garantia, não fica mais restrita aos padrões liberais de limitação negativa da ação estatal, mas vem acrescida de um plus transformador, em que a concretização de obrigações/prestações que importam na transfiguração do status quo efetivamente uma posição de primazia no espaço de legitimação constituído pela função de garantia e, com isso, a distribuição clássica das funções dos poderes públicos não mais está sujeita a uma separação rigorosa, com o objetivo de reforçar uma estrutura de fiscalização, mas, noutro sentido, se apresenta mais flexível, voltada a uma finalidade de cooperação, baseada na perspectiva de que há uma unidade inexorável no Estado para a realização de valores éticos substanciais positivados constitucionalmente e intensamente reclamados pela população a qual está, de alguma maneira, expressa em um atribuição executiva peculiar ao espaço público, sem que se limite às tarefas próprias do Poder Executivo.” MORAIS, Jose Luis Bolzan. Crises do Estado, Democracia Política e Possibilidades de Consolidação da Proposta Constitucional. In: CANOTILHO, JOSÉ GOMES CANOTILHO; STRECK, Lenio Luiz. Entre discursos e culturas jurídicas. Boletim da Faculdade de Direito, Universidade de Coimbra. Coimbra: Editora Coimbra, 2006. pp. 29-30.

${ }^{10}$ Importante relatar que não há, segundo o entendimento adotado, essencialidade na separação dos poderes. Na verdade, não há essencialidade ou natureza objetiva de tais competências. Como J. D. Ville mostra, as divisões funcionais e de competência decorrem de vários fatores. As histórias e formações nacionais determinam ordens de distribuição variadas, e com variações temporais significativas. Não há o essencialismo sobre a distribuição de poderes. VILLE, M. C. J. Constitutionalism and separation of powers. Indianapolis: Liberty fund, 1998. pp.6-19

11 "A necessidade e urgência de concretização de (nosso) modelo de Estado Democrático de Direito impõe repensar as nossas necessidades democráticas, nos induzindo a reconstrução da democracia representativa exercida através de "poderes" distintos - embora harmônicos entre si-, e reclama que todo ordenamento jurídico e todos os poderes políticos devam estar voltados à sua realização." MORAIS, Jose Luis Bolzan de. Crises do Estado, Democracia Política e Possibilidades de Consolidação da Proposta Constitucional. In: Boletim da Faculdade de Direito: : Studia Iuridica, n. 89, Coimbra: Ed. Coimbra, 2006. p. 36

12 "Nada obstante, Legislativo, Executivo e Judiciário exercem um controle recíproco sobre as atividades de cada um, de modo a impedir o surgimento de instâncias hegemônicas, capazes de oferecer riscos para a democracia e para os direitos fundamentais. Note-se que os três Poderes interpretam a Constituição, e sua atuação deve respeitar os valores e promover os fins nela previstos. No arranjo institucional em vigor, em caso de divergência na interpretação das normas constitucionais ou legais, a palavra final é do Judiciário. Essa primazia não significa, porém, que toda e

Revista de Direito Brasileira | Florianópolis, SC | v. 22 | n. 9 | p.29-49 |Jan./Abr. 2019 
Por outro lado, acresce-se à esta problemática o fato do Judiciário atuar como uma força contra-majoritária, a qual, todavia, recai sobre a figura pendular anteriormente descrita, o que pode significar tanto uma atuação progressista quanto conservadora. Em outras palavras, de certo modo, sob uma visão distorcida ${ }^{13}$ da democracia atual como a vontade da maioria e não como a conciliação da vontade de todos; o Judiciário teria a função de se impor em defesa das minorais como uma força contra a "ditadura da maioria", daí sua legitimidade e importância para tanto. Acresce-se, assim, ao debate, uma dificuldade contra-majoritária, fruto mesmo das teorias democráticas liberais e de suas modificações. O que supera até mesmo a questão jurídica e atinge a própria concepção de democracia e a democratização das instituições de decisão ${ }^{14}$.

Além disso, a dificuldade contra-majoritária traz a lume as deficiências do Poder Legislativo face a uma democracia representativa a qual mais que representar os interesses do povo busca-se representar os seus financiadores de campanha e interesses pessoais, os quais não necessariamente possuem conteúdo ilegal. Tais interesses pessoais, por exemplo, podem buscar obedecer aos anseios e valores do seu eleitorado para que possa se reeleger. Isto gera um descrédito no que atine aos representantes eleitos e questiona a própria noção constitucional de que todo poder emana do povo através de seus representantes eleitos, segundo o que dispõe o Artigo $1^{\circ}$, parágrafo único e art. 14 da Constituição Brasileira ${ }^{15}$.

Sob outro ponto de vista, argumenta-se que a legitimidade do Supremo Tribunal Federal decorre da sua principal tarefa de "guardião da Constituição". Assim sendo, cumpre-lhe velar pelos direitos fundamentais e dos valores protegidos constitucionalmente dentre eles a democracia. Por conseguinte, o STF funciona como protetor dos valores democráticos e tem legitimidade para se sobrepor às decisões que advieram dos poderes eleitos. Segundo este entendimento, as decisões judiciais não seriam políticas no sentido de livre escolha, de discricionariedade plena, assim como não poderiam ser guiadas puramente pela razão pública ou por ideologias, mas deveriam ser construídas de forma racional, persuasiva e fundamentada na Constituição, em observância, assim, ao seu dever de motivação ${ }^{16}$.

qualquer matéria deva ser decidida em um tribunal. Nem muito menos legitima a arrogância judicial.”. BARROSO, Luís Roberto. Op. Cit. p. 15

${ }^{13}$ Distorcida na medida que a democracia não se cuida do governo da maioria, mas do governo de todos. Neste sentido, "Povo, já não foi tomado como termo preexistente (da ideologia, da filosofia do Estado, da teoria da democracia), porém mais simplesmente como a totalidade de indivíduos realmente residentes no território do Estado: como uma 'multiplicidade em si diferenciada, mista, constituída em grupos, mas organizada de forma igualitária e não discriminatória'.". MÜLLER, Friedrich. Quem é o povo? A questão fundamental da democracia. Trad. Peter Naumann. $3^{\text {a }}$ edição. São Paulo: Ed. Max Limonad. p. 109.

14 "Para melhor esclarecer os meios através dos quais tal premissa se torna factível, necessário uma releitura da definição do adjetivo democrático, trazendo a tônica para o cidadão - e não apenas para o povo - e, com isso, penetrar nos meandros processuais, onde as garantias constitucionalmente previstas dão ao indivíduo meios de assegurar que ele se confronte com o posto e busque um aprimoramento do debate democrático. Mais que isso, necessário fazer a distinção entre democracia participativa e democracia representativa para enfim podermos evidenciar que a representatividade já não é mais capaz de sozinha realizar o autêntico ideário democrático, tão aspirado para a realização de uma sociedade justa e solidária. "RIBEIRO, Darci Guimarães; SCALABRIN, Felipe. O papel do processo na construção da democracia: para uma nova definição da democracia participativa. In: Revista SCIENTIA IURIS, Londrina, v. 13, nov. 2009, pp. 156-157.

15 "Artigo $1^{\circ}$ - A República Federativa do Brasil, formada pela união indissolúvel dos Estados e Municípios e do Distrito Federal, constitui-se em Estado Democrático de Direito e tem como fundamentos: I - a soberania; II - a cidadania; III - a dignidade da pessoa humana; IV - os valores sociais do trabalho e da livre iniciativa; V - o pluralismo político. Parágrafo único. Todo o poder emana do povo, que o exerce por meio de representantes eleitos ou diretamente, nos termos desta Constituição. "Artigo 14. A soberania popular será exercida pelo sufrágio universal e pelo voto direto e secreto, com valor igual para todos, e, nos termos da lei, mediante: I - plebiscito; II - referendo; III - iniciativa popular.

${ }^{16}$ Os riscos da politização da justiça, sobretudo da justiça constitucional, não podem ser totalmente eliminados. A Constituição é, precisamente, o documento que transforma o poder constituinte em poder constituído, isto é, Política em Direito. Essa interface entre dois mundos dá à interpretação constitucional uma inexorável dimensão política. Nada obstante isso, ela constitui uma tarefa jurídica. Sujeita-se, assim, aos cânones de racionalidade, objetividade e motivação das decisões judiciais, devendo reverência à dogmática jurídica, aos princípios de interpretação e aos

Revista de Direito Brasileira | Florianópolis, SC | v. 22 | n. 9 | p. 29-49 |Jan./Abr. 2019 
No entanto, mesmo devendo o STF motivar as suas decisões através das normas constitucionais, é cediço que as decisões jurídicas partem de uma dimensão política predominante contida na própria ideologia que os juízes carregam consigo. Até mesmo porque as decisões impactam e dizem respeito à realidade sociopolítica, não estando, portanto, dissociada desta. Além disso, é uma falácia achar que os juízes podem se despir de sua memória de vida, de suas crenças, sua experiência, sua ideologia e de suas emoções no momento de decidir, sendo, dessa forma, imparcial ${ }^{17}$. Portanto, inevitável se apresenta um certo decisionismo político nas decisões pelos juízes, e, especialmente, os juízes constitucionais ${ }^{18}$.

Contudo, se por um lado os juízes não podem fugir desta dimensão política que gera um risco de decisões distantes de uma vontade da sociedade submetendo esta a um governo dos juízes, por outro lado, é igualmente verdadeiro a importância destes na defesa de direitos fundamentais face a uma casa legislativa e um poder executivo cego e ineficiente às demandas sociais ${ }^{19}$. Tendo isto em vista, parte da doutrina acredita que mecanismos como o amicus curiae e as audiências públicas sejam o peso de equilíbrio desta balança, de forma a conferir legitimidade democrática aos tribunais. Isto porque seriam capazes de aproximar a sociedade do Supremo Tribunal Federal, dando voz ao povo nestes espaços que pouco frequentaram no curso da História. E, é sobre este ponto que se coloca o presente trabalho.

Com isso, busca-se analisar como e se as audiências públicas podem contribuir para a legitimação democrática no controle de constitucionalidade brasileira. E, como estas refletem nos limites da capacidade institucional do Judiciário no que diz respeito a construção de uma sociedade democrática. Para tanto, se fará uma breve exposição crítica de como audiências encontram-se previstas no ordenamento jurídico brasileiro e como estas já foram aplicadas pelo Supremo Tribunal Federal (STF).

Uma vez que prevista na legislação acerca da ação direta de inconstitucionalidade e na ação declaratória de constitucionalidade perante o STF, optou-se por restringir o estudo sobre as audiências públicas ocorridas nestas ações; ou seja, no controle de constitucionalidade concentrado.

\section{AS AUDIÊNCIAS PÚBLICAS}

\subsection{A inserção das Audiências Públicas nos Processos de Controle de Constitucionalidade concentrado}

A audiência pública é instrumento de que pode fazer uso o Juiz-Relator ${ }^{20}$ do Supremo Tribunal Federal (STF), em sede de controle de constitucionalidade concentrado, para a requisição de informações adicionais, através da convocação de pessoas com experiência e autoridade na matéria, no caso de necessidade de esclarecimentos de matéria ou circunstância de fato ou de

precedentes21. Uma corte constitucional não deve ser cega ou indiferente às consequências políticas de suas decisões, inclusive para impedir resultados injustos ou danosos ao bem comum ou aos direitos fundamentais. Mas somente pode agir dentro das possibilidades e dos limites abertos pelo ordenamento jurídico.”. BARROSO, Luís Roberto. Op. Cit. p.18

${ }^{17}$ Este assunto será aprofundado no item 3.2

${ }^{18}$ TEIXEIRA, Anderson Vichinkeski. Ativismo Judicial: nos limites entre racionalidade jurídica e decisão política. In: Revista Direito GV, SÃO PAULO 8(1), jan-jun.2012, p. 51.

p. 51

${ }^{19}$ Segundo o entendimento adotado, tal questão também está no âmbito da ideologia, ao passo que ao legislativo é imperativo seguir, em tese, à vontade dos eleitores. Dessa forma, uma atuação de supressão e não efetivação de direitos por parte do legislativo pode ser explicada pela configuração ideológica dos mesmos.

20 Artigo 21, XVII do Regimento Interno do Supremo Tribunal Federal. Disponível em http://www.stf.jus.br/portal/cms/verTexto.asp?servico=legislacaoRegimentoInterno. Acesso em 28/03/2016.

Revista de Direito Brasileira | Florianópolis, SC | v. 22 | n. 9 | p.29-49 |Jan./Abr. 2019 
notória insuficiência de informações existentes nos autos ${ }^{21}$. Assim sendo, após a manifestação dos legitimados ativos e passivos no âmbito do controle de constitucionalidade ${ }^{22}$ o relator pode requisitar a realização de audiência pública antes do seu julgamento.

Com o intuito de regular tais audiências, o STF editou uma emenda regimental (n.29) ao seu regimento interno em 18/02/2009. No que atine ao objeto desta pesquisa, esta emenda acrescentou dois incisos (XVII e XVIII) ao Artigo 13 conferindo o Presidente deste mesmo Tribunal a possibilidade de convocar audiências públicas, e acrescentou mais dois incisos (XVII e XVIII) ao Artigo 21 no mesmo sentido do Artigo 13, mas no que se refere ao Relator. A emenda acrescentou, ainda, ao Artigo 154, o inciso III e um parágrafo único, possibilitando a marcação de audiências públicas e regulamentando o procedimento destas audiências.

De acordo com o Artigo 154, parágrafo único do Regimento Interno do STF, as audiências públicas serão convocadas pelo Relator e pelo Presidente deste Tribunal através de um despacho convocatório no qual se fixará o prazo para indicação das pessoas que serão nela ouvidas ${ }^{23}$. No curso da audiência deve ser garantida a participação das diversas correntes de opiniões ${ }^{24}$. Ao Ministro que presidir a audiência cumpre selecionar as pessoas a serem ouvidas, a divulgação da lista de habilitados, a ordem dos trabalhos no curso desta e a fixação de tempo para a manifestação de cada $u^{25}$. O regimento interno impõe ainda que o depoente se limite ao tema ou questão em debate $^{26}$ e que a audiência seja transmitida na TV Justiça e na Rádio Justiça ${ }^{27}$. Por fim, os trabalhos produzidos neste devem ser registrados ou juntados aos autos do processo ou podem ser arquivados no âmbito da Presidência ${ }^{28}$. Por fim, determina-se que se houver casos omissos, estes, devem ser resolvidos pelo Ministro que convocou a audiência ${ }^{29}$.

Apesar de prevista desde a publicação da Lei nº 9868 em 1999, a primeira audiência pública somente veio a ser realizada pela primeira vez em 2007, pelo Ministro Ayres Britto, relator da ADI $\mathrm{n}^{\circ}$. 3510 na qual se impugnava dispositivos da Lei de Biossegurança (Lei 11.105/2005), caso comumente conhecido por: "pesquisas com células-tronco embrionárias" 30 . No despacho de requisição da audiência o Min. Ayres Britto ${ }^{31}$ justifica que

\begin{abstract}
Daqui se deduz que a matéria veiculada nesta ação se torna de saliente importância, por suscitar numerosos questionamentos e múltiplos entendimentos a respeito da tutela do direito à vida. Tudo a justificar a realização de audiência pública, a teor doß $1^{\circ}$ do Artigo $9^{\circ}$ da Lei 9.868/99. Audiência, que, além de subsidiar os Ministros deste Supremo Tribunal Federal, também possibilitará uma maior participação da sociedade civil no enfrentamento da controvérsia constitucional, o que certamente legitimará ainda mais a decisão a ser tomada pelo Plenário desta nossa colenda Corte. (grifo nosso)
\end{abstract}

Observa-se, assim, que o Ministro do STF justifica a audiência pública não só na obtenção de informações técnicas adicionais, mas também com vista à conferir maior legitimidade à sua

21 Artigo $9^{\circ}, \quad \S 1^{\circ}$ e Artigo 20, $\$ 1^{\circ}$ da Lei $\mathrm{n}^{\circ}$. 9868/99. Disponível em: http://www.planalto.gov.br/ccivil_03/leis/L9868.htm. Acesso em 28/03/2016.

22 Conforme disposto no Artigo 6, 7 e 8 da Lei no. 9868/99. Disponível em: http://www.planalto.gov.br/ccivil_03/leis/L9868.htm. Acesso em 28/03/2016.

${ }_{23}$ Artigo 154, parágrafo único, inciso I do Regimento Interno do Supremo Tribunal Federal.

${ }^{24}$ Artigo 154, parágrafo único, inciso II do Regimento Interno do Supremo Tribunal Federal.

${ }^{25}$ Artigo 154, parágrafo único, inciso III do Regimento Interno do Supremo Tribunal Federal.

${ }^{26}$ Artigo 154, parágrafo único, inciso IV do Regimento Interno do Supremo Tribunal Federal.

${ }^{27}$ Artigo 154, parágrafo único, inciso V do Regimento Interno do Supremo Tribunal Federal.

${ }^{28}$ Artigo 154, parágrafo único, inciso VI do Regimento Interno do Supremo Tribunal Federal.

${ }^{29}$ Artigo 154, parágrafo único, inciso VII do Regimento Interno do Supremo Tribunal Federal.

30

Retirado

de:

http://www.stf.jus.br/portal/jurisprudencia/listarJurisprudencia.asp?s1=\%28ADI\%24.SCLA.+E+3510.NUME.\%29+ OU+\%28ADI.ACMS.+ADJ2+3510.ACMS.\%29\&base=baseAcordaos\&url=http://tinyurl.com/av7pz4c. Acesso em $30 / 03 / 2018$.

${ }^{31}$ http://www.stf.jus.br/portal/audienciaPublica/audienciaPublica.asp?tipo=realizada\#. Acesso em30/03/2018. Revista de Direito Brasileira | Florianópolis, SC | v. 22 | n. 9 | p. 29-49 |Jan./Abr. 2019 
decisão através da participação da sociedade civil. A partir desta manifestação exemplificativa e da leitura dos demais despachos realizados por outros ministros para convocação de audiências públicas $^{32}$, pode-se concluir que essas audiências possuem dupla finalidade para esta Suprema Corte: a de informar-se melhor acerca de questões técnicas, e também, de conferir-lhe maior legitimidade democrática à suas decisões. Em suma, especialmente sobre esta questão da legitimidade democrática, o $\mathrm{STF}^{33}$ considera que as audiências públicas cumprem com tal objetivo na medida que permitem uma maior aproximação da Corte Constitucional com a sociedade civil (com a opinião pública), promovendo assim uma jurisdição constitucional mais democrática.

Portanto, da leitura do texto legal, verifica-se que através do previsto no Artigo $9^{\circ}, \S 1^{\circ}$ e Artigo $20, \S 1^{\circ}$ da Lei $9868 / 99$, o STF parece buscar a sua democratização em sede de controle de constitucionalidade através de uma maior aproximação com outros atores sociais para além daqueles que desempenham as funções estatais ou os demais legitimados (ativos e passivos) no processo de interpretação constitucional. Tais audiências seriam assim uma tentativa de minimizar a crítica acerca da dificuldade contra-majoritária e do dilema já exposto sobre a legitimidade.

Assim sendo, a seguir, se buscará verificar através de uma análise empírica da legislação, dos fundamentos doutrinários sobre o assunto e das audiências já realizadas por este tribunal, se essas audiências podem cumprir este papel democrático ou se estão fadas a se tornarem mero instrumento burocrático como forma de justificar a democratização de suas decisões.

\subsection{Breves comentários acerca da legislação pertinente}

Conforme visto no item anterior a audiência pública, na visão do STF, pretende contribuir para a participação social na formação do convencimento do julgador fortalecendo a democracia. Mas quem de fato pode participar?

A Lei 9.868/99, no que se refere aos dispositivos legais pertinentes, dispõe sobre "depoimentos de pessoas com experiência e autoridade na matéria", o que pode significar uma limitação das pessoas à serem habilitadas a participar da audiência. Isto porque restringira-se a participação das pessoas que o Ministro Relator considerasse especialistas técnicos no assunto pertinente ao controle de constitucionalidade concentrado ajuizado. Contudo, isto vai de encontro a própria finalidade de aumentar a participação democrática e contribui para que a jurisdição constitucional seja mais elitizada e afastada das lutas sociais ${ }^{34}$. Isto porque, pela mera leitura da norma, extrair-se-á que somente aqueles com "expertise” poderiam compor as audiências públicas, excluindo assim os movimentos sociais que não buscam trazer informações técnicas mas, muitas vezes, a sua própria experiência vivida ${ }^{35}$.

\footnotetext{
${ }^{32}$ No total, até o presente momento foram realizadas pelo STF, 18 audiências públicas, sendo 9 delas realizadas no controle de constitucionalidade concentrado (ADC e ADI). Para mais informações acerca dos despachos para convocação dessas audiências, acessar: http://www.stf.jus.br/portal/audienciaPublica/audienciaPublica.asp?tipo=realizada\#. Acesso em 30/03/2016.

${ }^{33}$ De acordo com a análise dos despachos convocatórios de audiências públicas analisados.

34 “A organização judicial estruturada de forma piramidal controlada no vértice por um pequeno grupo de juízes de alto escalão, onde o prestígio e a influência social do juiz dependem de sua posição na hierarquia profissional, acaba perpetuando, o ethos profissional dominante e fortalece o espírito corporativista, o que, na prática, contribui para um isolamento social do judiciário, fechando-o, enquanto a sociedade em que ele se assenta vai de diversificando e tornase cada vez mais plural." SANTOS, Boaventura de Sousa. Para uma revolução democrática da justiça. $3^{a}$ edição, revista e ampliada. . São Paulo: Editora Cortez, 2007. p. 66.

${ }^{35}$ Cumpre ressaltar o retrocesso epistemológico que isso apresenta na atualidade à luz do pensamento de Boaventura de Souza Santos: "Sucede contudo que, também como referi, o avanço do conhecimento das ciências naturais e a reflexão epistemológica que ele tem suscitado têm vindo a mostrar que os obstáculos ao conhecimento científico da sociedade e da cultura são de facto condições de conhecimento em geral, tanto científico-social como científico-natural. Ou seja, o que antes era a causa de maior atraso das ciências sociais é hoje o resultado do maior avanço das ciências naturais." (SANTOS, Boaventura de Sousa. Um discurso sobre as ciências. 5a edição. São Paulo: Cortez. 2008. p. 70) Revista de Direito Brasileira | Florianópolis, SC | v. 22 | n. 9 | p.29-49 |Jan./Abr. 2019
} 
Dada esta limitação participativa a priori, e ainda o fato de o Relator que convocou a audiência possuir discricionariedade na escolha de quem poderá participar nesta, entende-se que seja necessária uma reforma legislativa no sentido de dispor sobre parâmetros mínimos que vinculem esta escolha. Tais parâmetros devem perquirir uma formação verissímil com a pluralidade existente na própria sociedade, e assim, que seja a mais heterogênea possível. Não se exclui, todavia, a necessidade de vinculação dos participantes com a temática em debate, o que, por outro lado, não significa a escolha exclusiva de especialistas como imposto pela literalidade desta lei.

Em relação ao tempo estabelecido, a legislação em análise não tece maiores comentários, optando por deixar ao arbítrio do julgado a determinação do tempo de manifestação de cada participante selecionado para a audiência pública sem fazer, ao menos, qualquer referência à observância do princípio da igualdade. Contudo, acredita-se que, levando em consideração uma constituição heterogênea adequada à pertinência temática no controle de constitucionalidade $s u b$ judice, deveria se estipular tempo de manifestação equânime entre os argumentos a serem trazidos pelos selecionados para compor a audiência. Assim sendo, aqueles que se colocam pela constitucionalidade deveriam dispor de mesmo tempo de exposição daqueles que se colocam pela inconstitucionalidade em observância ao princípio da igualdade. Sendo que dentro destes macros grupos (da inconstitucionalidade e da constitucionalidade), cada um também deveria dispor do mesmo tempo para manifestação. Por fim, considera-se importante observar que o tempo deve ser suficientemente hábil e razoável para uma exposição tendo em vista a complexidade do tema. Além disso, uma vez que não há qualquer menção a observância de um parâmetro isonômico, há um real risco de que tal arbítrio venha a construir uma audiência não democrática onde um determinado argumento ou grupo tenha mais tempo para expor suas ideias do que outro, afetando assim à uma das finalidades para a qual se propõe.

Por fim, registra-se uma das considerações acerca da legislação acima mencionada que se considera mais problemática do ponto de vista democrático. Refere-se aqui à livre disposição de que goza o julgador para arquivar ou juntar aos autos do processo os trabalhos da audiência pública. Assim sendo, se o julgador não considerar que seja o caso ele pode descartar todo o trabalho realizado em audiência desprezando a participação popular no âmbito dessas audiências, sem a necessidade de fundamentar o pedido. Tendo isto em vista, o juiz pode optar por simplesmente ignorar toda a manifestação realizada nessas audiências e concentrar o julgamento na sua própria racionalidade e não tornando público aos demais ministros o conteúdo destas audiências. Por outro lado, cumpre ressalvar que tal precariedade estaria parcialmente compensada pela imposição legal de que as audiências devem ser públicas e divulgadas junto a Rádio e TV Justiça ${ }^{36}$. Contudo, há aqui um alto risco à concepção democrática que também atinge a arbitrariedade em relação à escolha ou não de realização das próprias audiências públicas, uma vez que caso os juízes constitucionais passem a não as realizar ou de arquivar as realizadas, descartando-as; isto pode levar à um descrédito da instituição que desestimularia a sua participação por diferentes setores da sociedade.

\subsection{Uma breve análise das audiências públicas já realizadas pelo Supremo Tribunal Federal no controle de constitucionalidade concentrado}

O STF até o momento ${ }^{37}$ já realizou 18 audiências públicas. Para a análise de como tem se dado tais audiências na prática do Tribunal foram selecionados aquelas que se realizaram no curso

\footnotetext{
${ }^{36}$ Conforme Artigo 154, parágrafo único, inciso V do Regimento Interno do STF, segundo o qual: "V - a audiência pública será transmitida pela TV Justiça e pela Rádio Justiça".

${ }^{37}$ Os dados coletados neste item foram retirados do próprio site do STF, consultado até o dia 30/03/2016.
}

Revista de Direito Brasileira | Florianópolis, SC | v. 22 | n. 9 | p. 29-49 |Jan./Abr. 2019 
do processo de controle de constitucionalidade abstrato, ou seja, em ação direta de inconstitucionalidade e ação declaratória de constitucionalidade, sendo elas abaixo reunidas ${ }^{38}$ :

\section{Audiências Públicas realizadas em sede de Controle de Constitucionalidade Concentrado Abstrato}

\begin{tabular}{|c|c|c|c|c|}
\hline N. ${ }^{o}$ & Min. Relator & Caso (n. ${ }^{\circ}$ do processo) & Data & $\begin{array}{l}\text { Número de } \\
\text { Participantes }^{39}\end{array}$ \\
\hline 1 & $\begin{array}{l}\text { Gilmar } \\
\text { Mendes }\end{array}$ & $\begin{array}{l}\text { Uso de depósito judicial } \\
\text { (ADI n. }{ }^{\circ} \text { 5.072) }\end{array}$ & $21 / 09 / 2015$ & 48 \\
\hline 2 & $\begin{array}{l}\text { Luís Roberto } \\
\text { Barroso }\end{array}$ & $\begin{array}{l}\text { Ensino Religioso em Escolas } \\
\text { Públicas (ADI n. }{ }^{\circ} 4.439 \text { ) }\end{array}$ & $15 / 06 / 2015$ & 34 \\
\hline 3 & Luiz Fux & 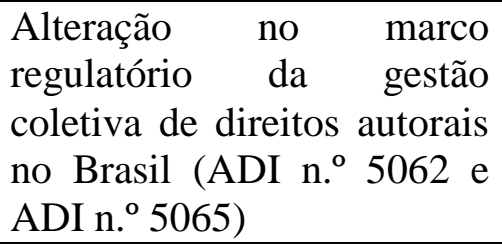 & $17 / 03 / 2014$ & 24 \\
\hline 4 & Marco Aurélio & $\begin{array}{l}\text { Programa "Mais Médicos" } \\
\text { (ADI n. }{ }^{\circ} 5037 \text { e ADI n. } \\
5035)\end{array}$ & $\begin{array}{l}25 / 11 / 2013 \text { e } \\
26 / 11 / 2013\end{array}$ & 23 \\
\hline 5 & Carmen Lúcia & $\begin{array}{l}\text { Biografias não autorizadas } \\
\text { (ADI n. }{ }^{\circ} 4815 \text { ) }\end{array}$ & $\begin{array}{l}21 / 11 / 2013 \text { e } \\
22 / 11 / 2013\end{array}$ & 17 \\
\hline 6 & Luiz Fux & $\begin{array}{l}\text { Financiamento de } \\
\text { Campanhas Eleitorais (ADI } \\
\text { n. }{ }^{\circ} \text { 4650) }\end{array}$ & $\begin{array}{l}17 / 06 / 2013 \text { e } \\
24 / 06 / 2013\end{array}$ & 36 \\
\hline 7 & Luiz Fux & $\begin{array}{l}\text { TV por Assinatura (ADI n. } \\
\underline{4.679}, \underline{\text { ADI n. } .^{\circ} 4.756} \text { e } \underline{\text { ADI }} \\
\underline{\left..^{\circ} 4.747\right)}\end{array}$ & $\begin{array}{l}18 / 02 / 2013 \text { e } \\
25 / 02 / 2013\end{array}$ & 30 \\
\hline 8 & Marco Aurélio & $\frac{\text { Proibição do uso de amianto }}{{\left.\text { (ADI } n^{\circ} 3.937\right)}^{\circ}}$ & $\begin{array}{l}24 / 08 / 2012 \text { e } \\
31 / 08 / 2012\end{array}$ & 35 \\
\hline 9 & Ayres Britto & $\begin{array}{l}\text { Pesquisas com células- } \\
\frac{\text { tronco embrionárias }}{\left.\text { n. }^{\circ} 3.510\right)^{40}} \text { (ADI } \\
\end{array}$ & $20 / 04 / 2007$ & 24 \\
\hline
\end{tabular}

Fonte: Realização própria

As audiências realizadas pelo STF, em sua maioria, são formadas em grande parte por técnicos, ou seja, especialistas no assunto principal de controle de constitucionalidade concentrado. Isto demonstra uma tendência exposta pelo próprio STF - seja nos despachos para convocar a audiência, seja em entrevistas e notícias fornecidas no site do tribunal - de fazer uso destas com o intuito de ampliar as informações colhidas sobre o objeto do processo. Isto é muito importante uma vez que mostra uma consciência por parte dos ministros daquela corte sobre as suas próprias

38 Dados sobre Audiências Públicas (dados retirados do site: http://www.stf.jus.br/portal/audienciaPublica/audienciaPublica.asp?tipo=realizada. Acesso 30/03/2016.

39 Retirado dos Relatórios de Atividades do STF. Disponível em: http://www.stf.jus.br/portal/cms/verTexto.asp?servico=sobreStfConhecaStfRelatorio. Acesso em 30/03/2016.

${ }^{40}$ Importante frisar que esta foi a primeira audiência pública realizada pelo STF, conforme já mencionado no início do item 2 deste trabalho. Ela se realizou em 2007 e, por este motivo, antes da edição da emenda regimental nº 29 em 2009 , que alterou o Regimento Interno do STF e passou a dispor sobre o procedimento das audiências públicas com a inclusão do parágrafo único ao Artigo 154 deste regimento. 
limitações. Cabe ao juiz, de fato, no exercício de suas atribuições, conhecer do direito, mas não de todos os problemas existente no mundo a fundo, principalmente aqueles atinentes ao início da vida, como foi debatido na audiência de $\mathrm{n}^{\circ} 9$ do quadro acima, ou sobre o funcionamento do mercado brasileiro de TC por assinatura na audiência $\mathrm{n}^{\circ} 7$.

Cumpre destacar que na maioria das audiências os Ministros que vão compor a turma para julgamento da ação em controle de constitucionalidade comparecem às audiências, assim como as partes (legitimados ativo e passivo). Por outro lado, a análise acerca das audiências realizadas não chega a qualquer conclusão definitiva de o quanto não heterogênea foram tais audiências, ou seja, sobre as razões que fariam com que tais audiências pudessem satisfazer uma formação heterogênea que se propôs no item anterior. Apesar disso, a clara quantidade de argumentos técnicos leva a conclusão de que há um déficit representativo, e que o equilíbrio acerca dos vários argumentos, contra ou a favor de uma (in)constitucionalidade, não podem ser alcançados. Isto não significa, todavia, que isto decorra de uma atitude dos Ministros Relatores nos respectivos processos, podendo decorrer também de quem se propôs a participar e que tenha enviado e-mail em tempo hábil para requisitar a participação. Por fim, a falta de pedidos de participação também pode ter vários outros fatores como os custos para ir até Brasília, por exemplo.

É possível observar, ainda, que em todas as audiências destacadas do quadro acima, os ministros, ao determinarem o tempo de exposição, costumam dispor entre 10-20 minutos para cada participante. É de ressalvar que isto pode gerar alguns problemas no mesmo sentido anteriormente mencionado no item acima. Isto porque, se houver o maior número de participante que defende um determinado argumento, o tempo disponível para este será maior que os outros, perpetuando-se assim uma desigualdade na participação. Ressalva-se, contudo, que os participantes enviam um relatório do que será exposto anteriormente que pode auxiliar os ministros à disporem melhor acerca de um tempo hábil.

Isto ainda nos parece relevante em relação a composição de participantes de que se tratou no parágrafo anterior. Assim sendo, por exemplo, na audiência $\mathrm{n}^{\circ} 3$ do quadro acima, uma vez que o Relator já recebeu a prévia do posicionamento dos possíveis participantes, poderia formar uma audiência igualitária, assim como dispor de um tempo igual para todos os posicionamentos. Com isso, poder-se-ia, ainda, promover até mesmo um espaço prévio em que os dois lados pudessem se reunir e dialogarem sobre a melhor distribuição de tempo, de modo a tornar a participação parte da própria estrutura das audiências públicas, ou seja, de sua formação.

Ademais, isto permite que as partes possam se preparar anteriormente às audiências para que suas exposições não ultrapassem o tempo determinado, já que este é disposto no despacho que chama para a realização da audiência pública. Por outro lado, não é possível fazer qualquer conclusão, tendo em vista os moldes deste trabalho, de modo a afirmar se este tempo que os ministros costumam dispor é de fato suficiente para exposição dos temas, até mesmo porque isto pode variar tendo em vista a complexidade do tema, por exemplo. Apesar disto, observa-se que durante as audiências as partes costumam ultrapassar o tempo, o que é corretamente compensado na exposição dos demais participantes.

Outro fato interessante acerca dos dados das audiências públicas é que nos despachos de chamada para a audiência sempre há menção acerca do tema de forma a restringir o conteúdo a ser exposto nesta. Por exemplo, na audiência $n^{\circ} .5$ foi vedado a exposição de relatos pessoais, e na audiência de $\mathrm{n}^{\circ}$. 3, 6, 7 os despachos excluem qualquer manifestação sobre interpretação jurídica. Essas restrições de conteúdo, seja no caso da exclusão à relatos pessoais e da interpretação jurídica, podem gerar uma limitação do enfoque democrático que se almeja, uma vez que excluem de antemão a manifestação de como o direito pode afetar sobre a realidade social, no primeiro caso; ou novas interpretações jurídicas não pensadas pelos juízes ou partes do processo, no segundo caso. Isto contraria a própria finalidade das audiências, ou seja, de aumento de informação coletada pelo Tribunal e a sua aproximação com a sociedade. 
Outro ponto a ser destacado destes despachos é que todos colocam os participantes (como optamos por denominar no quadro acima) como expositores, palestrantes. O que se reflete na forma como se realizaram as audiências, no sentido de que eram, de fato, mais um local de reunião de diferentes manifestações orais do que um local de diálogo ou de debate. Em outras palavras, até o momento estas audiências não formam um diálogo entre os participantes, o que é intrínseco em uma democracia participativa e deliberativa ${ }^{41}$.

Por fim, cumpre mencionar que todas as audiências públicas realizadas obedeceram a determinação do Regimento Interno do STF, nº 29 (Artigo 154, parágrafo único), segunda a qual as audiências devem ser sempre públicas. Sobre este ponto, nota-se ainda que são poucos os ministros - que não o relator da ação em controle de constitucionalidade - que participaram das audiências. Contudo, a transcrição da audiência é realizada e, até o momento, sempre foi juntada aos autos do processo, ou seja, até o momento não houveram casos de arquivamento destas. Assim sendo, mesmo sendo pouco os ministros que compareceram às audiências, todos tiveram acesso ao conteúdo desta. Contudo, não foi possível chegar a qualquer resultado conclusivo acerca da utilização destas por parte dos ministros do STF porque nem sempre os argumentos nos votos são mencionados indicando a sua origem na audiência e por conta de alguns casos não terem ainda sido julgados $^{42}$.

A seguir, investigar-se-á se estas audiências públicas da forma como foram realizadas contribuem para a democratização do STF no controle de constitucionalidade concentrado.

\section{UMA CONTRIBUIÇÃO PARA A DEMOCRATIZAÇÃO DA JURISDIÇÃO CONSTITUCIONAL OU UMA TENTATIVA PARA TANTO?}

\subsection{Democratização da Jurisdição Constitucional}

Da análise das audiências públicas realizadas no STF no item anterior como possibilidade de democratização deste tribunal no âmbito da jurisdição constitucional destacam-se dois elementos: aqueles que participaram e o seu procedimento.

O Min. Gilmar Mendes, em seu voto na Ação Direta de Inconstitucionalidade nº. 3510/2007 (audiência $n^{\circ} 9$ do quadro), deixa claro que a partir da realização das audiências públicas, fica evidente a legitimidade democrática do STF para o julgamento em controle de constitucionalidade. Nas palavras do ministro ${ }^{43}$ :

O Supremo Tribunal Federal demonstra, com este julgamento, que pode, sim, ser uma Casa do povo, tal qual o parlamento. Um lugar onde os diversos anseios sociais e o pluralismo político, ético e religioso encontram guarida nos debates procedimental e argumentativamente organizados em normas previamente estabelecidas. As audiências públicas, nas quais são ouvidos os expertos sobre a matéria em debate, a intervenção dos amici curiae, com suas contribuições jurídica e socialmente relevantes, assim como a intervenção do Ministério Público, como representante de toda a sociedade perante o Tribunal, e das advocacias pública e privada, na defesa de seus interesses, fazem desta Corte também um espaço democrático. Um espaço aberto à reflexão e à argumentação jurídica e moral, com ampla repercussão na coletividade e nas instituições democráticas.

Assim sendo, incorporando a tese de Peter Habërle, à que faz referência, o Ministro entende que o STF passa a ser legitimado democraticamente para tanto na medida em que passa a abrir suas

\footnotetext{
${ }^{41} \mathrm{O}$ assunto sobre o diálogo na democracia participativa e deliberativa será exposto de forma mais profunda no próximo item.

${ }^{42}$ É o caso das audiências de $n^{\circ}$. 1, 2, 3, 4, 7 e 8 .

43 Voto na ADI n 3510 disponível em: www.stf.gov.br/arquivo/cms/noticiaNoticiaStf/anexo/ADI3510GM.pdf. Acesso em 15/04/2016.
}

Revista de Direito Brasileira | Florianópolis, SC | v. 22 | n. 9 | p.29-49 |Jan./Abr. 2019 
portas para a participação de toda a sociedade. Segundo esta autor, a interpretação constitucional não é fato exclusivo do Estado, dizendo respeito a todos ${ }^{44}$. Nesta ordem de ideias, a corte constitucional brasileira, através deste procedimento, estaria aplicando a teoria de Peter Häberle para o qual, todos os cidadãos deveriam ser chamados para a interpretação constitucional na medida em que são atingidos por esta, aproximando assim a Constituição à realidade social. De acordo com o autor, quanto mais clamor social uma dada lei gerar, mais rigoroso deve ser o tribunal no controle da participação da sociedade na decisão acerca da sua constitucionalidade ou inconstitucionalidade $^{45}$ cujos interesses os juízes constitucionais devem estar atentos e ouvi-los. Assim fazendo,

(...) uma ótima conformação legislativa e o refinamento interpretativo do direito constitucional processual as condições básicas para assegurar a pretendida legitimação da jurisdição constitucional no contexto de uma teoria da Democracia. $^{46}$

Afirma-se ainda que a partir da realização das audiências públicas a dificuldade contramajoritária da jurisdição constitucional restaria superada em aplicação da teoria dos diálogos institucionais ${ }^{47}$ uma vez que permite o diálogo para com os representantes dos poderes Legislativo e Executivo. O que, todavia, ainda não soluciona em definitivo a problemática aqui colocada, tendo em vista o déficit representativo de tais instituições como colocado no início deste trabalho. Em outras palavras, o diálogo institucional apesar de importante não é capaz de esgotar os pontos de vista contidos no âmbito social.

Por outro lado, mesmo a participação nas audiências públicas podendo ocorrer para além das instituições, estas não são capazes de revelar uma legitimação democrática, ou a democratização deste tribunal, nos termos como são colocados a partir destas teorias. Observou-se que no que diz respeito a quem é chamado ou selecionado a participar e o modus operandi destas apresentam características que se afastam da ideia de democracia que tenha por pressuposto a participação dos cidadãos nas decisões que lhes afetem, ou seja, de uma democracia participativa e de democraciarepresentativa. Na medida em que a maioria dos participantes verificados naquelas audiências são especialistas e sendo sua estrutura expositiva e não dialógica-dialética, verifica-se que este instrumento serve muito mais de interdisciplinarização das decisões do tribunal, informando os juízes de assuntos que fogem da seara jurídica do que como forma de deliberação política como defende o Ministro Gilmar Mendes no voto acima destacado. Conforme visto nos despachos do

${ }^{44}$ HÄBERLE, Peter. Hermenêutica Constitucional: a sociedade aberta dos intérpretes da Constituição para a interpretação pluralista e "procedimental" da constituição. Trad. Gilmar Mendes. Porto Alegre: Sergio Antonio Fabris Editor, 2002. pp. 23-24

45 "No desenvolvimento dessa orientação algumas considerações devem ser feitas: existem leis - a lei sobre o ensino superior, as reformas do Código Penal, como aquela referente ao §218, que descriminalizava parcialmente o aborto, a lei que disciplina o funcionamento do comércio -, que despertam grande interesse na opinião pública. Essas leis provocam discussões permanentes e são aprovadas com a participação e sob o controle rigoroso da opinião pública pluralista.”. Id. pp. 45-46.

46 Id. p. 49.

47 “O fundamento legitimatório da democracia é concebido a partir da capacidade das instituições em efetivar direitos fundamentais que compõem uma estrutura básica da sociedade, bem como do impacto que as decisões institucionais podem ter sobre o sistema institucional como um todo. Partindo desses dois paradigmas - capacidade institucional e efeitos dinâmicos -, Adrian Vermeule propõe alguns arranjos institucionais capazes de compatibilizar, na leitura do próprio autor, quatro principais valores democráticos: (I) a imparcialidade, que consiste na exclusão de um regime governamental baseado em interesses pessoais; (II) a responsabilidade política (ou prestação de contas), determinando que as razões que fundamentam uma decisão governamental devem ser postas ao debate e contestadas pelos cidadãos envolvidos nos reflexos dessas decisões; (III) a transparência, isto é, o efetivo conhecimento sobre o conteúdo das decisões governamentais por todos os interessados; e (IV) a deliberação, como procedimento de troca de informações para a formação da opinião e da vontade política.”. ZETTEL, Bernardo Barbosa; GANEM, Fabrício Faroni Ganem; BOLONHA, Carlos Alberto Pereira das Neves. O modelo democrático-deliberativo: possibilidades institucionais. In: Direito, Estado e Sociedade. n.41, jul/dez 2012. p.77.

Revista de Direito Brasileira | Florianópolis, SC | v. 22 | n. 9 | p. 29-49 |Jan./Abr. 2019 
Min. Luiz Fux para a chamada das audiências, estes chegam a mencionar que as manifestações nestas não devem apresentar caráter jurídico.

Assim sendo, estas parecem mais solucionar a questão colocada por Dworkin em relação ao "juiz-Hércules" do que responder ao dilema contra-majoritário. Em suma, a aproximação do Tribunal se dá com uma parcela limitada da sociedade e especialmente à comunidade científica e de especialistas, mas esta aproximação não alcança uma deliberação política as quais se encontram na própria estrutura dos órgãos políticos, mas sim a mitigação de um déficit de conhecimento especializado dos ministros cujo conhecimento técnico de todas as áreas do saber é impossível.

Logo, apesar de não suprirem a necessidade de democratização dos tribunais como almejado pelas teorias constitucionais, isto não faz com que elas sejam de todo descartáveis, uma vez que servem de instrumento de auxílio técnico-científico da corte constitucional.

\subsection{Limites da capacidade institucional}

Conforme afirmado no início do presente trabalho, as discussões acerca da democratização da jurisdição constitucional subjaz a descrença ${ }^{48}$ nos demais poderes (Executivo e Legislativo) para a defesa e efetivação dos direitos fundamentais previstos constitucionalmente. Assim sendo, a sociedade percebe, cada vez mais, que o poder legislativo, casa esta de representação da vontade popular legitimada pelo sufrágio universal, pouco representa os seus interesses. Neste sentido, o aumento pela procura dos Tribunais está incluso nesse contexto e funciona como alternativa para alcançar os direitos face a debilidade crônica dos mecanismos de sua implementação ${ }^{49}$. Portanto, os tribunais brasileiros, nesse contexto, passam a significar o simulacro das lutas sociais. Isto faz com que haja uma demanda por democratização dos tribunais não como espaço de representação, crítica que muito se faz no que respeita ao dilema contra-majoritário apresentado anteriormente, mas no seu próprio juízo decisório.

A demanda por democratização do processo decisório não é fato exclusivo do Poder Judiciário, mas reflete a limitação da compreensão da democracia como mera representação política através do direito ao voto. Assim sendo, a partir da crise da representação, a compreensão acerca do Estado Democrático de Direito, perpassa pela necessidade de verificar se as decisões das instituições políticas e jurídicas correspondem ao ditames democráticos impostos constitucionalmente. Por conseguinte, o problema da legitimidade passa da constituição do poder para decidir (poder político) para a estrutura das decisões, ou seja, como elas são formadas. Em outras palavras: da democracia representativa para a democracia deliberativa (ou participativa) ${ }^{50}$.

Sobre o processo democrático deliberativo, destacar-se-á os três modelos normativos de democracia defendida por Habermas, sendo eles: o liberal, o republicano e o da teoria do discurso ${ }^{51}$. Para o autor o poder na democracia liberal tem por função agregar os interesses sociais privados,

\footnotetext{
${ }^{48}$ Nas palavras de Ansart vivemos em um tempo de "fim dos amores políticos", enquanto isso, Agambem realiza o mesmo diagnóstico frente aos sistemas representativos. AGAMBEM, G. O que é o contemporâneo e outros ensaios. Chapecó: Argos, 2009. ANSART, P. Mal-estar ou fim dos amores políticos. História e perspectiva, Uberlândia, jul.dez.; jan.-jul. 2001; 2002. 55-80.

${ }^{49}$ SANTOS, Boaventura de Sousa. Para uma revolução democrática da justiça. $3^{\mathrm{a}}$ edição revista e ampliada. São Paulo: Editora Cortez, 2007. pp. 14-16.

50 "El modelo deliberativo de democracia, en oposición al representativo, institucionaliza y consigue la inserción del discurso, como un proceso abierto y colectivo en la toma de posiciones, dentro todos los ámbitos del Estado -en el caso de las audiencias públicas: en el proceso judicial-. Tal prototipo de Estado obtiene su fuerza legitimadora de la estructura discursiva de una formación de la opinión y la voluntad común gracias a la racionalidad de sus resultados." GIUFFRÉ, Carlos Ignacio Giuffré. Audiencias públicas informativas en el Poder Judicial: una mirada a través de la obra de Jürgen Habermas. Disponível em: https://www.academia.edu/21561380/Audiencias_p\%C3\%BAblicas informativas_en el_Poder_Judicial_una_mirad a a trav\%C3\%A9s_de la obra_de J\%C3\%BCrgen_Habermas. Acesso em 16/03/2016.

${ }^{51}$ HABERMAS, Jürgen. Três modelos normativos de democracia. Lua Nova [online], n. 36, 1995. pp. 39-53. http://dx.doi.org/10.1590/S0102-644519950002000003.
}

Revista de Direito Brasileira | Florianópolis, SC | v. 22 | n. 9 | p.29-49 |Jan./Abr. 2019 
de modo que o Estado deve administrar os interesses privados para que estes se direcionem para fins coletivos. Por outro lado, a democracia republicana parte do pressuposto de que a sociedade possui autonomia e, com isso, autodetermina-se sob a consciência de que a sociedade só existe numa lógica de dependência recíproca, devendo-se assim viver em solidariedade. Em outras palavras, o indivíduo no exercício de sua cidadania está orientado para o bem comum e a integração social.

Tendo isto em vista, na democracia republicana o poder é comunicante e é guiado pela autodeterminação do povo, cumprindo ao Estado proteger (positivamente) essa prática cidadã por meio da institucionalização da liberdade pública. Por outro lado, para os liberais existem valores que transcendem a vontade política de um povo, ou seja, há uma lei superior que seria capaz de servir de parâmetro para a uma satisfatória busca pluralista de interesses diferentes e conflitantes. Assim sendo, para os republicanos, a legitimidade da lei decorre do procedimento democrático de sua construção, significando, assim, a vontade política prevalecente.

O processo político, por sua vez, na democracia liberal, se dá pela concorrência, ou seja, pela disputa de poder através da barganha, e o vencedor é escolhido pelo povo de acordo com os interesses individuais de cada um. Já, para os republicanos não cuida-se de barganha mas de argumento racional, de modo que, o processo político é formado pelo juízo coletivo da vontade política prevalecente, segundo uma comunicação pública (persuasiva) orientada para um entendimento que se dá através de diálogo ${ }^{52}$. Assim sendo, enquanto que no modelo liberal a uma coordenação dos interesses individuais prevalecentes, no modelo republicano há uma cooperação formada pelo diálogo acerca do bem comum.

Contudo, para Habermas estes dois modelos possuem suas vantagens e desvantagens, possuindo em comum um ponto: as condições de comunicação e dos procedimentos na formação da opinião e da vontade política. Assim sendo, ele propõe um terceiro modelo, que chama de Teoria do Discurso, o qual visa um procedimento de deliberação e de tomada de decisões ideal.

Para tanto, ele observa que na democracia republicana defende-se a autogestão descentralizada do poder burocrático e autonomizado do Estado e, consequentemente, a deliberação ocorre através da auto-organização dos cidadãos. Já na democracia liberal é o Estado de Direito que possui a prerrogativa de garantir um procedimento democrático capaz de equilibrar as relações de poder e os interesses, através do estabelecimento e reafirmação de normas neste sentido. No entanto, de acordo com a teoria do discurso, que ele propõe, o procedimento político de formação da opinião e da vontade comum tem papel central, e são os princípios do Estado de Direito e os direitos fundamentais, enquanto pressupostos comunicativos deste procedimento institucionalizado que são capazes de corrigir o idealismo excessivo dos republicanos ou as discrepâncias das relações de poder ignoradas pelos liberais durante este procedimento, estabelecendo, assim, deliberações democráticas.

Em suma, para Habermas o procedimento institucionalizado no Estado de Direito e nos pressupostos comunicativos é capaz de corrigir as desigualdades nas relações de poder (político) e no discurso nas deliberações democráticas. Além disso, nessa democracia deliberativa, os participantes não se preocupam somente com os seus próprios interesses mas escutam e levam em consideração os interesses dos outros se estes forem compatíveis com os valores de Justiça dos quais decorrerão regras de discurso capazes de superar as diferenças mencionadas.

Porém, que valores são esses? Quais valores são justos? É possível se chegar a uma concepção acerca da Justiça em uma sociedade cujos valores são tão plurais? Em síntese, o que Habermas desconsidera e que Chaïm Perelman atentou no seu livro "Ética e Direito", é que tais valores são escolhidos arbitrariamente ${ }^{53}$ de acordo com preconcepções, ideologias e emoções que

\footnotetext{
${ }^{52}$ Ibid. pp. $42-43$

53 "Nesse empenho de justificação das regras para delas eliminar, na medida do possível, a arbitrariedade deve deterse num princípio injustificado, num valor arbitrário. Um sistema de justiça, por mais adiantado que seja, não pode eliminar toda a arbitrariedade, senão, na verdade, já não seria um sistema normativo: estabeleceria uma necessidade
}

Revista de Direito Brasileira | Florianópolis, SC | v. 22 | n. 9 | p. 29-49 |Jan./Abr. 2019 
cada um contém. Logo, as escolhas de tais valores não são construídas a partir de juízo imparcial ou absolutamente neutro, e nem o é possível de o ser, mesmo que se tente sob o fundamento de uma pura racionalidade. Em outras palavras, mesmo a argumentação racional não é dotada de imparcialidade e neutralidade pura, mas campo de argumentação e deliberação ${ }^{54}$ que não estão livres de ideologias, preconcepções e emoções ${ }^{55}$ como bem percebeu Iris Marion Young $^{56}$ :

\begin{abstract}
Além disso, a imparcialidade é tão impossível para os burocratas que tomam decisões quanto para os outros agente morais. É simplesmente impossível para os tomadores de decisão de carne e osso, estejam eles no governo ou não, adotar o ponto de vista da razão transcendental quanto tomam decisões divorciando-se de filiações e compromissos de grupo que constituem suas identidades e definem sua perspectiva da vida social.
\end{abstract}

Assim sendo, a deliberação sob o ponto de vista institucional como defendido por Habermas, que se pretende imparcial, acabam por perpetuar as desigualdades das relações de poder que pretende superar. Nesse sentido, eles geram muito mais exclusão, ou seja, menor participação, do que inclusão ou uma maior participação social na tomada de decisão. Portanto, na medida em que se pretende criar regras para a garantia de uma legitimidade democrática do procedimento decisório, isto por si só, acaba por gerar a exclusão social pela restrição de diferentes formas de discurso existentes.

Consequentemente, destas regras, assim como ocorre em relação as regras impostas para o procedimento das audiências públicas, decorre a exclusão participativa/deliberativa, seja pelo custo de, por exemplo, ir até Brasília ou, ainda, pelo custo de elaboração das propostas de manifestação,

lógica ou uma universalidade experimental e seu caráter normativo desapareceria imediatamente. (...) Como todo valor é arbitrário, não existe justiça absoluta, inteiramente fundamentada na razão. Para ser mais preciso, não existe justiça absoluta, exceto a respeito de seres idênticos que, seja qual for o critério escolhido, sempre farão parte da mesma categoria essencial. (...) O caráter emotivo dos valores que estão na base de todo sistema normativo é que faz que a aplicação da justiça pareça ser uma operação da qual toda afetividade não está inteiramente excluída. Um sistema de justiça pode, por inteiro, ressentir-se da coloração emotiva nele propagada pelo valor fundamental do qual ele constitui um desenvolvimento racional. (...) É por isso que um ser apaixonado por justiça não se contentará em aplicar estrita e cegamente a regras que decorrem do seu sistema normativo; sempre pensará no fundamento arbitrário de seu sistema que não é, e não pode ser, um sistema perfeito. Não esquecerá que, ao lado dos valores reconhecidos por ele, existem outros valores aos quais algumas pessoas se devotam e pelos quais se sacrificam, e que sempre é possível uma revisão dos valores. (...) Assim é que, embora a justiça pareça ser a única virtude racional, que se opõe à irregularidade dos nossos atos, à arbitrariedade das nossas regras, não se deve esquecer que sua ação mesma é fundamentada em valores arbitrários, irracionais, e que a estes se opõem outros valores aos quais um sentimento de justiça refinado não pode ser totalmente insensível.”. PERELMAN, Chaïm. Ética e Direito. 1ª edição. Trad. Maria Ermantina Galvão G. Pereira. São Paulo: Ed. Martins Fontes, 1996. pp. 59-66.

${ }^{54}$ Ibid. pp. 93-94.

${ }^{55}$ Nesse mesmo sentido e em crítica mesmo a teoria democrática de Habermas e a concepção normativa racional, Iris Marion Young afirma que: “A razão imparcial visa à adoção de um ponto de vista exterior a situações concretas de ação, uma 'visão a partir de lugar nenhum', transcendental, que não traga consigo a perspectiva, os atributos, o caráter e os interesses de qualquer sujeito ou conjunto de sujeitos particulares." (p. 309), no entanto, "Em uma discussão democrática na qual os participantes expressam suas necessidades, ninguém fala de um ponto de vista imparcial, nem apela a um interesse geral" (p. 318) como defendido por Habermas. Assim sendo, "Nessa passagem de uma expressão de desejo a uma demanda de justiça, os participantes do diálogo não fazem uma pausa em suas situações específicas para adotar um ponto de vista universal e compartilhado. Apenas passam da necessidade de considerar os interesses próprios ao reconhecimento das demandas dos outros. Segundo essa interpretação, as alegações normativamente válidas são as generalizáveis no sentido de que podem ser reconhecidas sem violar os direitos dos outros nem submetêlos à dominação. Os interesses assim generalizáveis podem ser, ainda assim, particulares, ligados à situação e às necessidades de um grupo em participar e, portanto, não compartilhados por todos.” (p. 318). Por fim, conclui que: “A insistência no ideal de imparcialidade, mesmo sendo ele impossível de atingir, funciona para mascarar a inevitável parcialidade de perspectiva que de fato orienta a deliberação moral.” (p. 327). YOUNG, Iris Marion. O ideal da imparcialidade e o público cívico. In: MIGUEL, Luis Felipe; DIROLI, Flavia (org.). Teoria política feminista: textos centrais. $1^{\mathrm{a}}$ edição. Rio de Janeiro: Editora Eduff. 2014. pp. 305-337.

56 Ibid. p. 326.

Revista de Direito Brasileira | Florianópolis, SC | v. 22 | n. 9 | p.29-49 |Jan./Abr. 2019 
tempo insuficiente, restrição temática, e domínio/conhecimento acerca da linguagem e do método de argumentação mais eficiente. Portanto, tais elementos, por si só, já representam diferenças entre interesses em jogo os quais somente são aprofundados dentro da institucionalização deliberativa nas audiências públicas. O próprio discurso institucionalizado é um produto completo de desigualdade na medida em que pressupõe um conhecimento técnico (regras do discurso) ${ }^{57}$ que não parte de uma relação igualitária. Por este motivo, igualmente, as audiências públicas não são capazes de aumentar a participação social e representar um campo deliberativo eficaz como se pretende, mas somente de mascarar a reprodução de poder e de injustiça ${ }^{58}$.

A participação mais ampla da sociedade junto a corte constitucional brasileira através da audiência pública pretende dar efetivo poder de decisão (em sentido amplo) sobre os assuntos que os afetem, incluindo-os na relação de poder. No entanto, estruturalmente, este objetivo parece impossível sob o ponto de vista acima analisado. Do que se conclui que o problema das audiências públicas não está nas finalidades, mas na sua estrutura, uma vez que se desenvolve através de estruturas sociais desiguais as quais não é capaz de solucionar tendo em vista o formato como se realizam na atualidade. Assim sendo, ela não é capaz de criar espaços deliberativos efetivamente democráticos de inclusão dos diversos interesses sociais, os quais demandariam uma participação nos planejamentos e no processo decisório do tribunal no curso do controle de constitucionalidade concentrado, por meio de uma sociedade já emancipada, ou seja, igual e livre.

\section{CONCLUSÃO}

A crise democrática atinge a todas as esferas de decisão, dentre as quais incluem-se aquelas tomadas pelo Supremo Tribunal Federal no controle de constitucionalidade concentrado. A fim de atingir tal objetivo e com isso ainda afirmar a sua legitimidade democrática enquanto garantidor dos direitos fundamentais face a crítica que permeia sobretudo o dilema contra majoritário, a corte constitucional brasileira busca diversos instrumentos dos quais se inclui as audiências públicas. Contudo, seja através da análise puramente do texto legal e das audiências públicas já realizadas pelo Supremo Tribunal Federal, percebe-se que estas possuem limitações insuperáveis que decorrem de seu próprio modelo institucionalizado. Tais limites subjazem sobretudo aqueles que dela participam e seu modus operandi.

Assim sendo, apesar do Supremo Tribunal Federal representar um elemento útil para articular práticas sociais emancipatórias nos últimos anos, ele movimenta-se em uma zona fronteiriça entre a debilidade institucional e as práticas sociais emancipatórias, de modo a transitar entre o conservadorismo e o espaço de emancipação das práticas sociais.

Apesar das críticas aqui realizadas às audiências, isto não significa que elas não tenham sua importância ou contribuição para o debate aqui tratado. O que aqui se verificou é que ela possui

\footnotetext{
57 "No ponto de passagem entre experiências e expressão é que se situa a sua intervenção dos produtores profissionais de discursivos. Nesse ponto, se instauram as relações entre os profissionais e os profanos, os significantes e os significados: os dominados que estão comprometidos com a consciências, ou seja, com a linguagem, encontram-se à mercê dos discursos que lhe são propostos, correndo o risco de sair da doxa para cair forçosamente na alodoxia, em todos os falsos reconhecimentos, aliás favorecidos pelo discurso dominante; e, no melhor dos casos, à mercê de seu porta-voz a quem compete fornecer-lhes os instrumentos de reapropriação de sua própria experiência. (...) A linguagem dominante destrói, desacreditando-o, o discurso político espontâneo dos dominados: deixa-lhes apenas o silêncio ou a linguagem artificial, cuja lógica já não é a do uso popular, sem ser a do uso erudito - linguagem deteriorada em que as "palavras difíceis" são utilizadas simplesmente para marcar a dignidade da intenção expressiva - e que, incapaz de transmitir algo de verdadeiro, real ou "sentido", desapossa seu utilizador da própria experiência que, segundo se presume, tal linguagem deveria exprimir.” BOURDIEU, Pierre. A distinção: crítica social do julgamento. São Paulo: Eusp; Porto Alegre: Zouk, 2007. pp. 130-131.

${ }^{58}$ Neste mesmo sentido, afirma Iris Marion Young no que atine à democracia deliberativa institucionalizada em: Activist Challenges to Deliberative Democracy. In: Political Theory, Vol. 29, No. 5. Outubro, 2001.p. 685. Disponível em: http://www.jstor.org/stable/3072534. Acesso em 29/01/2015.
}

Revista de Direito Brasileira | Florianópolis, SC | v. 22 | n. 9 | p. 29-49 |Jan./Abr. 2019 
limites que lhe são institucionalmente instransponíveis. No entanto, de fato ampliam a participação para além dos legitimados para a ação direta de inconstitucionalidade e para a ação declaratória de constitucionalidade, mas que não cumpre com os almejos de uma democracia deliberativa inclusiva.

Logo, apesar do esforço do STF neste sentido, o tribunal possui um limite na sua capacidade institucional que jaz na sua estrutura e o qual, por esta razão, não pode superar mesmo com a criação de novos instrumentos como a audiência pública. Isto porque o seu processo decisório traz consigo a própria ideia de dominação contida na velha figura triangular onde o Juiz se coloca de forma distante as partes que se encontram na base daquela figura.

Na epígrafe deste trabalho destacamos uma fala de Deleuze em uma entrevista na qual afirma que: “(...) a maioria é ninguém e a minoria é todo mundo”. É sobre esta afirmativa que deve se basear qualquer proposta doutrinária que pretenda dar efetividade aos ideias de uma democracia deliberativa. Assim sendo, para a construção de espaços de real deliberação democráticas deve-se buscar uma participação realmente inclusiva, capaz de reunir os diferentes interesses presentes na sociedade. Esta reunião, deve visar um diálogo o qual, por sua vez, deve decorrer sem regras prédeterminadas que reforcem as desigualdades e, assim, exclusões sociais.

\section{REFERÊNCIAS}

AGAMBEM, G. O que é o contemporâneo e outros ensaios. Chapecó: Argos, 2009.

ANSART, P. Mal-estar ou fim dos amores políticos. História e perspectiva, Uberlândia, jul.-dez.; jan.-jul. 2001; 2002. pp. 55-80.

BARROSO, Luís Roberto. Judicialização, Ativismo Judicial e Legitimidade Democrática. In: Revista (Syn)theses, volume 5, n.1, 2012. pp. 1-29.

BOLONHA, Carlos Alberto Pereira das Neves; GANEM, Fabrício Faroni; RANGEL, Henrique. A Supremacia Judicial em sua Essência: para além do casuísmo teórico. In: Sequiência, n. 66, Florianópolis. jul. 2013. pp. 261-282. Doi: http://dx.doi.org/10.5007/21777055.2013v34n66p261.

BOURDIEU, Pierre. A distinção: crítica social do julgamento. São Paulo: Eusp; Porto Alegre: Zouk, 2007. pp. 371-433.

CADEMARTORI, Luiz Henrique Urquhart; ESTEVES, João Luiz Martins. A ideologia da neutralidade: uma abordagem sobre o juspositivismo normativista e seus limites frente à democracia social. Scientia Iuris, Londrina, v.17, n.2, pp.193-210, dez.2013. DOI: 10.5433/21788189.2013v17n2p193.

CORRÊA, Felipe. Poder e Participação. PLURAL, Revista do Programa de Pós-Graduação em Sociologia da USP, São Paulo, v.19.2, 2012, pp.113-128.

GIUFFRÉ, Carlos Ignacio Giuffré. Audiencias públicas informativas en el Poder Judicial: una mirada a través de la obra de Jürgen Habermas. Disponível em: https://www.academia.edu/21561380/Audiencias_p\%C3\%BAblicas_informativas_en_el_Poder_ Judicial_una_mirada_a_trav\%C3\%A9s_de_la_obra_de_J\%C3\%BCr̈gen_Habermas. Acesso em 16/03/2016. 
HÄBERLE, Peter. Hermenêutica Constitucional: a sociedade aberta dos intérpretes da Constituição para a interpretação pluralista e "procedimental" da constituição. Trad. Gilmar Mendes. Porto Alegre: Sergio Antonio Fabris Editor, 2002.

HABERMAS, Jürgen. Três modelos normativos de democracia. Lua Nova [online], n. 36, 1995. pp. 39-53. http://dx.doi.org/10.1590/S0102-644519950002000003.

LIBERAL, José Roberto Bernardi; NETO, Zaiden Geraige. A participação popular na Formação do Convencimento do Julgador. In: Direito, Estado e Sociedade, n.44, jan/jun 2014. pp. 60 a 82.

MARONA, Marjorie Corrêa; ROCHA, Marta Mendes. As audiências públicas no Supremo Tribunal Federal: ampliando sua legitimidade democrática? In: Teoria e Sociedade, $\mathrm{n}^{\mathbf{o}}$ 21, jan-jul. 2014. pp. 53-86.

MIRANDA, Jorge. Juízes para os Tribunais! In: Constituição e Cidadania. Coimbra: Editora Coimba, 2003. pp. 421-422.

MIRANDA, Jorge. Quem elege os juízes do Tribunal Constitucional? In: Constituição e Cidadania. Coimbra: Editora Coimba, 2003. pp. 399-401.

MORAIS, Jose Luis Bolzan. Crises do Estado, Democracia Política e Possibilidades de Consolidação da Proposta Constitucional. In: CANOTILHO, JOSÉ GOMES CANOTILHO; STRECK, Lenio Luiz. Entre discursos e culturas jurídicas. Boletim da Faculdade de Direito, Universidade de Coimbra. Coimbra: Editora Coimbra, 2006. pp. 15-46.

MÜLLER, Friedrich. Quem é o povo? A questão fundamental da democracia. Trad. Peter Naumann. $3^{\text {a }}$ edição. São Paulo: Ed. Max Limonad.

PERELMAN, Chaïm. Ética e Direito. $1^{a}$ edição. Trad. Maria Ermantina Galvão G. Pereira. São Paulo: Ed. Martins Fontes, 1996.

PIERCE JR, R. J. What Do the Studies of Judicial Review of Agency. Admin. L. Rev. (Forthcoming). Washington, 2010.

RIBEIRO, Darci Guimarães; SCALABRIN, Felipe. O papel do processo na construção da democracia: para uma nova definição da democracia participativa. In: Revista SCIENTIA IURIS, Londrina, v. 13, Nov. 2009. pp. 155-168.

SANTOS, Boaventura de Sousa. Para uma revolução democrática da justiça. $3^{\text {a }}$ edição revista e ampliada. São Paulo: Editora Cortez, 2007.

SANTOS, Boaventura de Sousa. Um discurso sobre as ciências. $5^{\mathrm{a}}$ edição. São Paulo: Cortez. 2008.

SUNDFELD, Carlos Ari, et. al. Controle de constitucionalidade e judicialização: o STF frente à sociedade e aos Poderes. Centro de Estudos Sociais América Latina Observatório da Justiça Brasileira. Universidade Federal de Minas Gerais - UFMG. Faculdade de Filosofia e Ciências Humanas. Sociedade Brasileira de Direito Público (SBDP). São Paulo: junho, 2011. 
TEXEIRA, Anderson Vichinkeski. Ativismo judicial: nos limites entre racionalidade jurídica e decisão política. In: Revista Direito GV, nº. 8(1). São Paulo. Jan-Jul. 2012, pp. 37-58.

VILLE, M. C. J. Constitutionalism and separation of powers. Indianapolis: Liberty fund, 1998.

YOUNG, Iris Marion. Activist Challenges to Deliberative Democracy. In: Political Theory, Vol. 29, No. 5. Outubro, 2001. p. 685. Disponível em: http://www.jstor.org/stable/3072534. Acesso em 29/01/2015.

YOUNG, Iris Marion. O ideal da imparcialidade e o público cívico. In: MIGUEL, Luis Felipe; DIROLI, Flavia (org.). Teoria política feminista: textos centrais. $1^{\mathrm{a}}$ edição. Rio de Janeiro:

Editora Eduff. 2014. pp. 305-337.

ZETTEL, Bernardo Barbosa; GANEM, Fabrício Faroni Ganem; BOLONHA, Carlos Alberto Pereira das Neves. O modelo democrático-deliberativo: possibilidades institucionais. In: Direito, Estado e Sociedade n.41, jul/dez 2012. pp. 64 a 106. 